Ambiances

anbiances Environnement sensible, architecture et espace urbain

$5 \mid 2019$

Phenomenographies. Describing urban and architectural atmospheres

\title{
TerriStories. Literary Tools for Capturing Atmosphere in Architectural Pedagogy
}

TerriStories. Outils littéraires pour saisir les ambiances dans le cadre pédagogique du projet d'architecture

\section{Klaske Havik}

\section{OpenEdition}

\section{Journals}

Electronic version

URL: http://journals.openedition.org/ambiances/2787

ISSN: 2266-839X

\section{Publisher:}

Direction Générale des Patrimoines - DAPA - MCC, UMR 1563 - Ambiances Architectures Urbanités (AAU)

\section{Electronic reference}

Klaske Havik, «TerriStories. Literary Tools for Capturing Atmosphere in Architectural Pedagogy », Ambiances [Online], 5 | 2019, Online since 20 December 2019, connection on 20 December 2019. URL : http://journals.openedition.org/ambiances/2787

This text was automatically generated on 20 December 2019.

\section{(†)

Ambiances is licensed under a Creative Commons Attribution-NonCommercial-NoDerivatives 4.0 International License. 


\title{
TerriStories. Literary Tools for Capturing Atmosphere in Architectural Pedagogy
}

\author{
TerriStories. Outils littéraires pour saisir les ambiances dans le cadre \\ pédagogique du projet d'architecture
}

\author{
Klaske Havik
}

1 By recognizing the potential of literary language in the description of architectural atmospheres, this contribution aims to confront the shortcomings of conventional pedagogical approaches in architecture that often fail to provide an in-depth understanding of the experiential aspects of place. To contribute to the development of appropriate instruments of analysis and design to read and describe urban atmosphere, this article combines two main insights: first, that it is of crucial importance to investigate site-specific atmospheres to understand how people experience the urban territories they use or inhabit; and second, that it is through literary devices that atmospheres can be read and described. By bringing together these insights, this article aims to propose pedagogical exercises that help students of architecture to develop a better understanding of the experiential aspects of site-specificity. By adding to the conventional tools of architects and planners a set of tools inspired by literature, it hopes to offer students in architecture more appropriate tools to describe, respond to, and produce site-specific atmospheres. The potential of this approach will be illustrated by presenting an example of the use of literary methods in architectural education, in Tampere, Finland.

\section{Site-Specific Atmospheres}

2 In the past decades, the theme of atmosphere has been surprisingly absent from architectural discourse and education. In late nineteenth-century aesthetic theory, there was an interest in the notion of stimmung (Pérez-Gómez, 2016), and architects 
such as Gottfried Semper explored the experiential aspects of architecture - Semper spoke about atmosphere, and addressed issues of architectural materiality in metaphorical using bodily terms, such as mound and hearth for architectural elements (Semper 1989 [1851]). From the times when modernist thinking and its related faith in scientific objectivity prevailed, to recent decades in which image-culture was celebrated and architecture was mediatized by means of icons made by "starchitects", it is evident that such notions as atmosphere, character and beauty have been pushed to the background of architectural discourse. Today, renewed interest in these themes is noticeable, and a growing number of architects, urban planners and students have rediscovered atmosphere as an essential quality of architecture and urban space. Contemporary architects, such as Kengo Kuma, Steven Holl, Peter Zumthor and Juhani Pallasmaa, have, in some cases explicitly, reclaimed atmosphere as a central concern in their work (Zumthor 1996, Havik, Tielens 2013). Alberto Pérez-Gómez holds a plea to give more attention to experiential factors, such as the perception of urban atmospheres in architectural and urban design, arguing that the central role of architecture is to provide attuned environments for inhabitants (Pérez-Gómez, 2016).

3 In recent years, atmosphere has been brought to the foreground as a field of research in philosophy and urban studies (Thibaud and Siret 2012, Griffero 2014). Like many aesthetic questions, whether we speak of art, architecture of poetry, it is hard to define exactly what is atmosphere. Like poetry, as Jorge Luis Borges argued, we may be able to truly know something only if we cannot define it (Borges 1968). German philosopher Böhme states that atmosphere is at stake precisely when subject and object meet, and thus that atmosphere relies on the presence of an experiencing subject (Böhme 2006, 2013). Therefore, not only objective parameters, such as materiality, shadow, light, dimension, temperature play a role in our atmospheric perception, but so do subjective factors, such as mood, memory, and sensitivity of the perceiving subject. Tonino Griffero, in his discussion of atmospheres as emotional spaces, suggests that it is this vagueness of atmosphere, the fact that we cannot grasp it objectively, that makes it philosophically interesting (Griffero 2016: 12). Harry Mallgrave, in his recent book From Object to Experience, argues that there is currently a shift taking place from seeing architecture as a matter of objects to a stronger focus on the experience of architecture - indeed, an interest in the question how people relate to their environment and how they perceive it. Mallgrave suggests that "the atmosphere of the human habitat should have a 'presence' or authenticity of feeling, one formed not only by the ingenious assembly or composition of materials but also by how we measure its emotional depth and richness - that is, how we read and internalize it" (Mallgrave 2018:120). Thus, if there is a challenge for architects, urban planners and researchers in these fields to develop a better understanding of site-specific atmospheres, there is a need to find appropriate pedagogical methods to teach them how to read such atmospheres. As Griffero argues, if we aim to better understand urban atmospheres, we need to find ways to produce "atmospheric description" which "designates a vague entity in a precise way" (Griffero 2016: 15). Taking seriously this suggestion of reading and describing atmospheres, the question emerges whether literary language may provide potential for pedagogical explorations into the topic of atmosphere. In literary descriptions of architecture in novels, stories and poems, atmosphere is often eloquently brought to the fore. In poetic descriptions, we find detailed account of how materials meet, and how texture, shadow or color may render emotional responses. As Gaston Bachelard observed, "poets are born phenomenologists, noting that things 
'speak' to them" (Bachelard, 1994: 28). The list of examples of evocative descriptions of architecture in novels and poems is vast, and range from the detailed descriptions of materiality, temperature and color in the library of Umberto Eco's The Name of the Rose to the sensorial descriptions of places of memory in Marcel Proust's In Search of Lost Times and the evocative accounts of shadow in Tanizaki's In Praise of Shadows. Tanizaki pointed out that our aesthetic appreciation of objects is not always "in the thing itself but in the patterns of shadows, the light and darkness, that one thing against the other creates" (Tanizaki 2001 [1933], 46). If literary writers are able to capture atmospheres in their work, the use of literary methods in architectural education may help to train architects, urban planners and researchers in this field to be equally sensitive to the atmospheric possibilities of place.

\section{Stories: Narrative Methods for Spatial Analysis and Design}

In search for appropriate theories and methods to teach architecture students how site-specific atmospheres can be studied and translated to responsible design approaches, we may thus turn our attention to literary devices. Indeed, literary descriptions often provide detailed information regarding experiential aspects of urban places, such as sensory perception, memory and atmosphere; aspects that remain largely untouched in architectural discourse. Literary language has the capacity to dwell on the complexities of spatial experience. Theorists such as Edward Hall (1966), Yi-Fu Tuan (1974) and Michel de Certeau (1984) argued that in order to understand how people relate to their environment, one should turn to the stories, which indeed contain valuable information about everyday life in cities, and tell about the relationship between people and places. Consequently, stories are helpful in the acknowledgment of different layers and perceptions of local urban cultures. In the past decade, a number of architects, writers and scholars brought this topic back to the stage of architectural and urban discourse, and have built up expertise about the relationship between architecture and literature and its potential for contemporary urban and architectural questions (Grafe, Havik \& Maaskant 2006, Nerdinger 2007, Edwards and Charley 2011, Gadanho and Oliveira 2013, Havik 2014, Havik and Oliveira 2016, Sioli and Jung 2018, Charley 2018).

5 Regarding the relevance of literary studies for architecture and the city, let me highlight three important perspectives: experience, use and imagination (Havik, 2014). First, literature allows us to address the experience of places in richer ways than architects usually tend to do. Evocative literary descriptions of spaces, whether in novels or poetry, often provide detailed information of how people experience architecture. While in architecture the visual and the formal tend to be dominant, literature often describes other sensory perceptions of spaces with great detail and intensity, and includes other aspects of experience that remain largely untouched in architectural discourse, such as atmosphere and memory. Second, literary narratives often reveal the social aspects of space - it is through the literary accounts of places that we can learn how they are used. Exploring the relationship between the activities of characters and the spatial setting of the novel, as well as that between writer and reader (and by extension architect-user) allows architects to consider the life of a building after its inauguration: a life marked by changing uses and users. Third, novels 
can be seen as sketches of another world, balancing between reality and imagination. If novels present constructions of another world, architectural designs are much alike: they give an account of a not yet existing situation. By studying the tools that writers employ in constructing their spatial imaginations, such as scripts and scenarios, we can learn new ways to imagine the city. Related to these perspectives, a number of literary devices come to the fore. In a literary narrative - the organisation of events in space and time in a story - places are intrinsically related to the activities of protagonists. Narrative analysis of urban places thus allows to consider place as a dynamic phenomenon, marked by changing uses and users. Character as a literary tool - looking through the eyes of another - places the author in a position of empathy. Stories are vehicles for empathy, able to make readers acquainted with the perspective of the "other". Indeed, this focus on empathy is part of plea for a more humanist understanding of architecture and urbanism.

\section{TerriStories: Social-spatial Narratives in Architectural Education}

6 The pedagogical approach TerriStories combines these two themes - atmospheres of spatial territories, and social-spatial inquiry through stories - by providing narrative methods for architects to investigate site-specific atmospheres and to make designs that take into account such atmospheric qualities. In the acknowledgement that literary language offers yet unexplored possibilities to conceptualize and produce qualitative atmospheres, the approach allows site specific atmospheres and the voices of local inhabitants to emerge. The idea for TerriStories was born in an educational context, and was first developed for the Summerschool of the Faculty of Architecture in Skopje, which took place in 2009, on the premises of a monastery in a mountainous area in North-Macedonia (Havik and Veldhuisen 2011).

7 Here, we introduced the idea of TerriStories to explore different characters of the territory, understanding these as human and non-human agents: light, water, wood, soil and man. Taking these characters as point of departure, we used storytelling methods to create for the students an awarenes of the biography of such aspects of place, and explore the reciprocity between these "characters", the territory, and the built environment.

In the following part of this contribution, I will highlight a more recent instance in which I have used this approach to make students aware of site-specific atmospheres, and to challenge them to use literary methods to arrive at more situated and engaged design proposals. I will expand on a project for a group of around sixty Master of Architecture students at the department of Architecture in Tampere, Finland. In this course, students had to study the relation between place and atmosphere by designing for and through stories. The assignment was to design a museum for the stories, characters and places of the Finnish Moomin graphic novels by Tove Jansson. These graphic novels present fictitious creatures whose adventures take place in landscapes characterized by trees, water, rocks and flowers - indeed, key elements of the Finnish landscape.

The studio developed the analysis of site-specific atmosphere and the design for the Moomin museum by means of four sub-tasks, each focusing on a particular theme, 
which was addressed by means of different narrative tools. The course, situated in the first year of the Master of Architecture Program, lasted one semester (sixteen weeks), and each phase was developed over a period of four weeks. Each of the tasks was introduced by means of a lecture providing architectural and literary references, explaining the proposed methods and providing a detailed account of the deliverables.

The first task, "finding place", focused on the choice of site and the analysis of sitespecific atmospheres. For this phase, descriptive tools were used to study the experiential qualities of a landscape. The second task, "placing characters", brought into action the characters of the stories. By studying the needs and wishes of characters, the students were asked to specify the relation between the site and the program. In this phase, the brief was specified towards the desired ambiance of the different spaces, and the composition of the project was sketched in plans and sections. The third task, "spatial stories" focused on the factor time, and challenged the students to imagine the different activities and events that would take place in the building and on the site. Here, through narrating the trajectories of visitors and staff of the museum, aspects of perception, movement and routing were further elaborated. Finally, the fourth task, "evoking atmosphere", related the study of architectural experience to questions of materiality, light, texture, and detail. Here, different instances of perception, from different users, were imagined through the poetic description and depiction of details, questioning how are spaces experienced.

Figure 1: The particular territory of Tampere, Finland, situated along a river between two lakes. Each of the four sites relates in a different way to the water

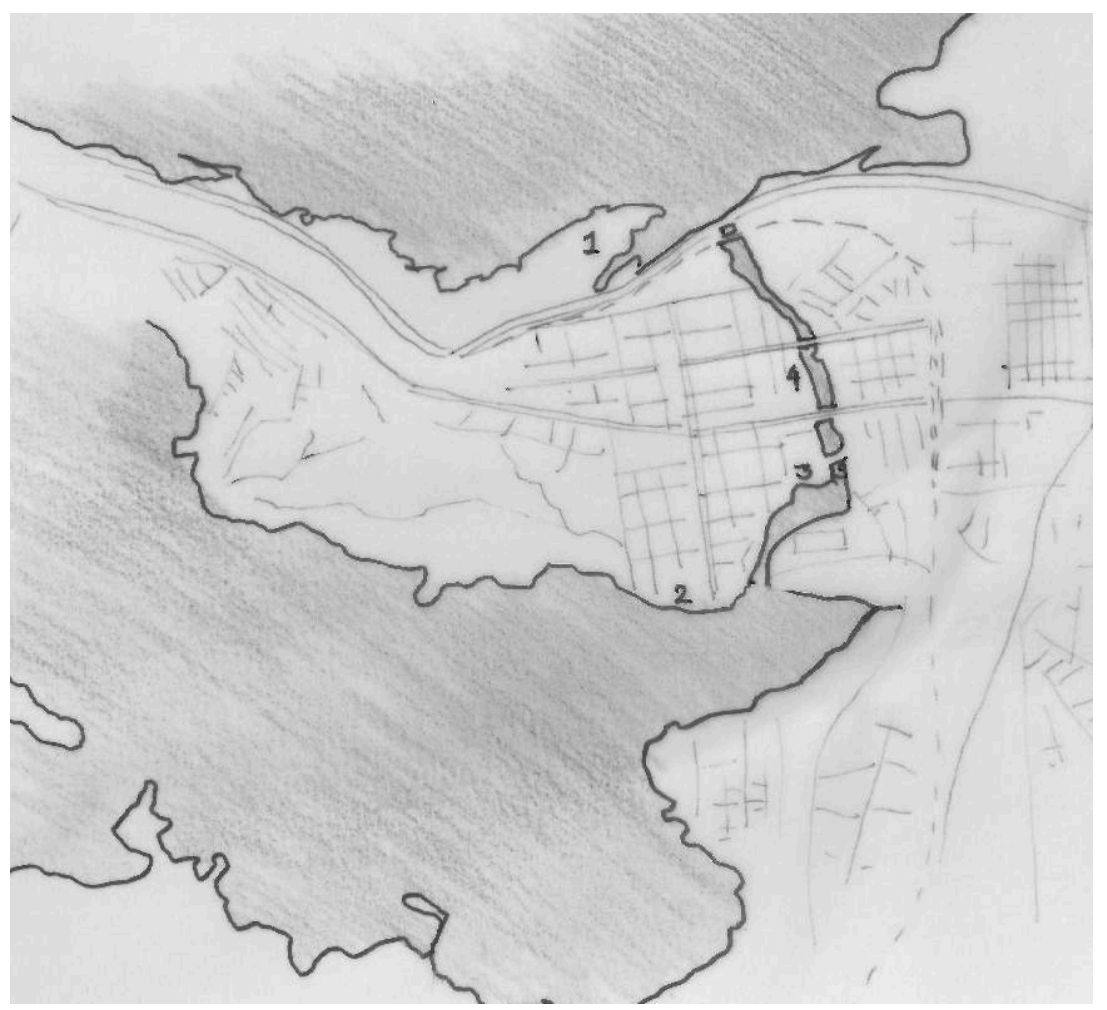

1 Rocks at the lakeside: Sarkaniemi amusement park

2 Edge of the city and water: Eteläpuisto park

3 Urban harbor square Laukontori

4 Tampere city center, river bank.

(c) Klaske Havik 


\section{Finding place: site-specificity}

The Finnish city Tampere is situated in a wooded landscape, between two lakes. The lakes are connected by a small river with a natural rapid. Due to the possibility to generate energy from the rapid, and due to the good connections to the coast over water, road and railway, the city became a flourishing industrial center in the late $19^{\text {th }}$ century. Like in many other industrial towns in Europe, the closure of the factories in Tampere, which defined much of the life in the city until the first half of the twentieth century, radically changed the urban identity of the city. A number of old factories located in the city center along the rapid in the city center became partly re-used for commercial and cultural purposes. The particular landscape setting of Tampere, with its present of water both at urban and more natural sites played a large role in the study of the site-specific atmospheres. For their project, the students were challenged to choose one out of four sites, which were located in different parts of Tampere, always close to a waterfront: two more urban and two more natural.

The first phase of the course concerned the study of four particular places in Tampere, in terms of their atmospheres and appropriateness for the suggested programme. What defines the atmosphere of a site? How can we capture site specific qualities on the one hand, and imagine atmospheres coming from the programme of the museum? As Danish theorist Niels Albertsen suggested: "sensing atmospheres requires our attention to which state we are in; how we sense ourselves in the surroundings we are part of." (Albertsen, 2012: 70)

13 Instead of giving students maps and data to study, the first task was to go and visit the four proposed sites without much prior knowledge, and to map the atmospheric qualities they perceived during these encounters with the sites. The primer for these site visits were the Moomin stories, graphic novels of friendly creatures, living in a valley, passing through landscapes with rocks and water, dark gloomy caves and sunlit orchards. In the first week, students were thus requested to read the Moomin stories and to visit multiple sites, and make choice for the site for their project. The required products were three-fold: a site map with main atmospheric characteristics perceived at the site visit; a collage of atmosphere on site and surroundings; and a short imaginative description of the new Moomin museum at the chosen site. The maps, collages and texts were presented during a plenary session with all students and tutors. Remarkably, the reading of the stories as a primer to the site visits resulted in imaginative site readings that often featured the fictional characters of the Moomins. 
Figure 2: "Finding Place" exercise by Jouko Loikkanen
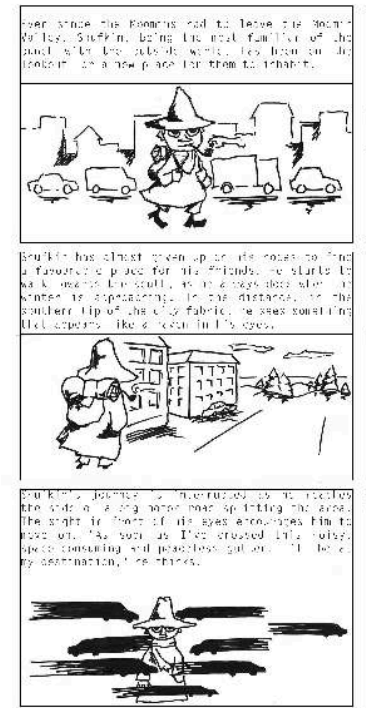

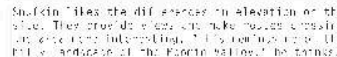
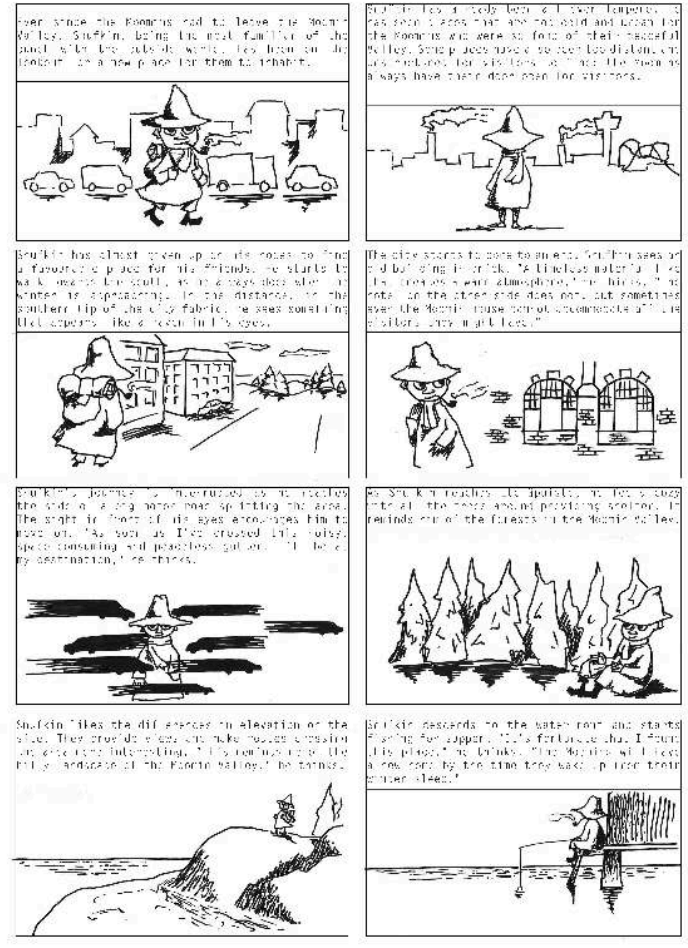

(c) Jouko Loikkanen

Figure 3a, 3b: “Finding Place" exercise by Lotta Aulamo, site reading and imagined project atmosphere

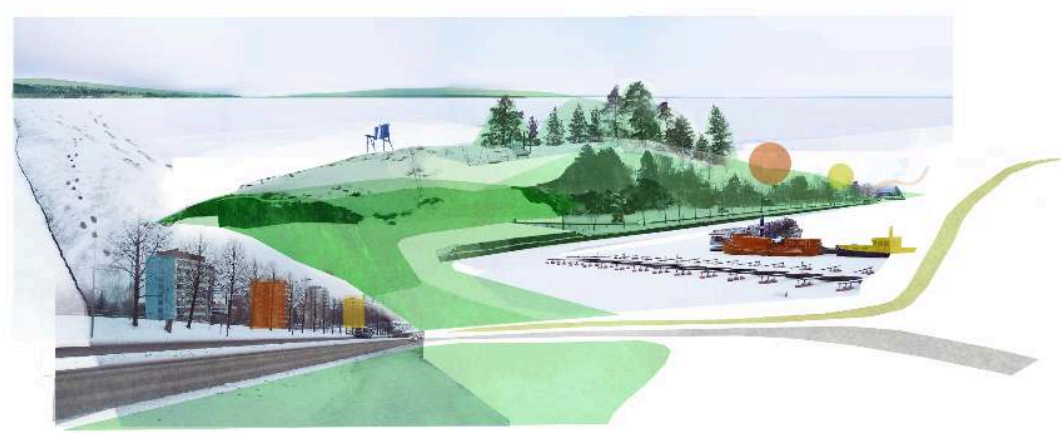

adventures in the landscape

tove Jansson and her woik have deall wilh big socie-
tal issues: treedom, equality and empathy, Her work also mediates wilder things ilike soltude, robelion, joy and a

Nature is cn important part of Janssons work. Muumins relationship lo the surrounding
becutiful and understanding.

The world that her creatures live in is filled with thrill and strong noturd

powers beyond their control särkannriemi, the cape in the
ling.

In my cessign I try to creote a fow between the visitor.

the place and

courage to take an Muuminh like-adventure to the sur

rounding landscopes of Nassiörvi and the city and form

the museum should offer wide spectrum of otmosphe

res from bubb:y adventures to olmost scary shadows

and to the calm hamony of a Mi:
meodow affer a good breakifast.

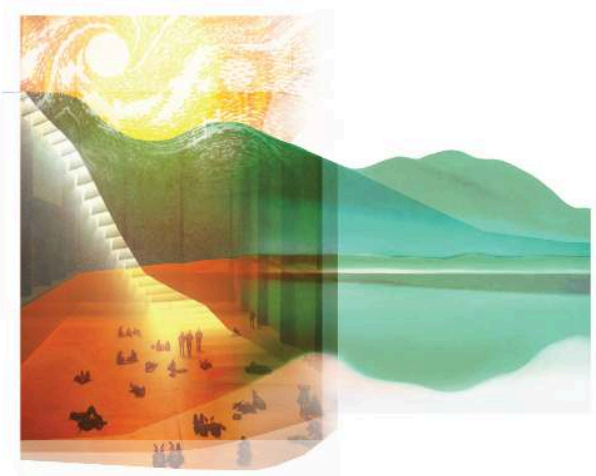

(c) Lotta Aulamo 


\section{Placing characters} interplay between the spatial organisation and the various characters related to the program and the site. In this phase, students were challenged to take distance from their own perspective and develop empathy for the experiences, needs and wishes of other characters. They imagined the lives of the occupants: the Moomin characters, represented in the building, as well as the visitors, both children and adults, and the museum staff. Imagining the space from the eyes of another character made it possible to study the program and its spatial requirements from different angles. At the same time, students were asked to think about the building itself as a character: what does it tell? Is it modest, proud, brutal, daring, friendly, strange, kind, stubborn, melancholic, inviting? of different characters: which spaces need to be high, which could be broad, narrow or steep, are there any contrasts between the different required spaces and in which way could different spatial requirements be combined? The requested deliverables included a specification of the brief both in square meters and in material and spatial qualities. The use of references from both literary and architectural sources was encouraged to express the desired ambiance of the difference spaces. Further, students delivered sketches of plans, sections and perspectives which explored the initial composition of the project, relating the different spaces to one another.

Figure 4: "Placing characters" exercise by Anna Luotolampi
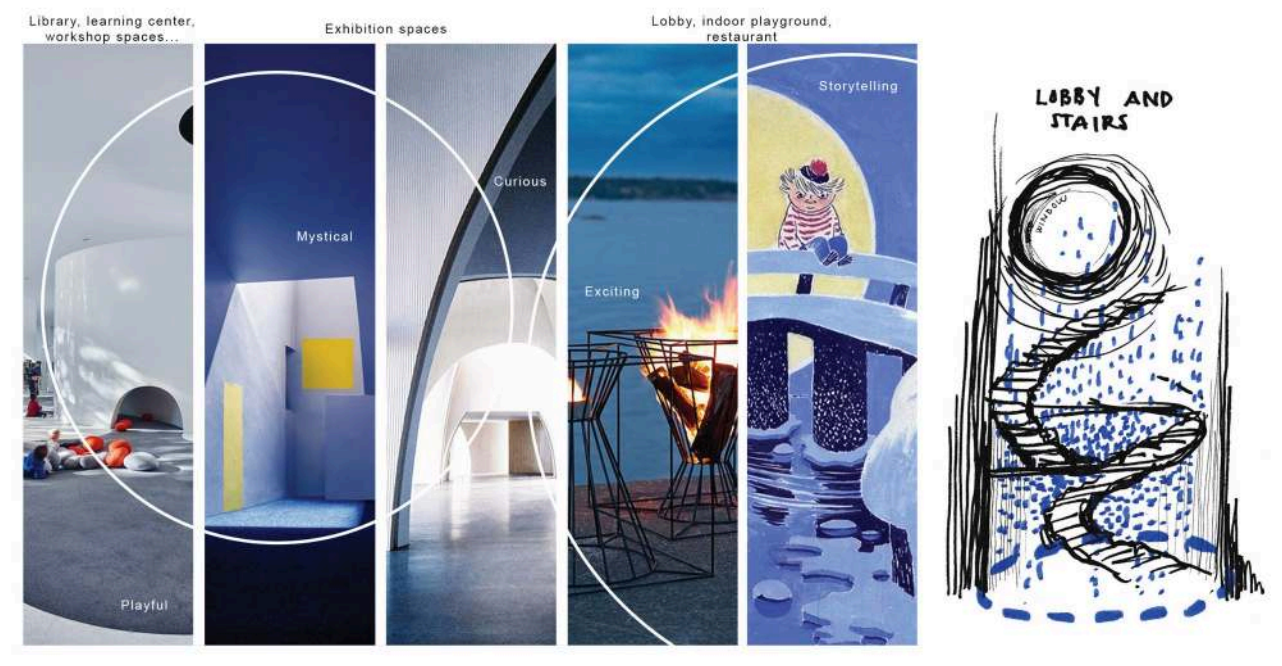

(C): Anna Luotolampi

\section{Spatial Stories}

The third task focused on the role of embodied perception in the design of the museum and explored the route through the building, between different spaces. Through the act 
of narration, the factor of time was introduced: if a narrative can be defined as the organisation of a series of events in time, thinking about architecture from a narrative perspective would imply that we might need to take into account the affordances (Gibson, 1979) of the project. By narrating the trajectories of the different characters (museum visitors, adults and kids, museum staff and passers-by), and imagining multiple possible events, such as a lecture, an exhibition opening or a concert, the students were challenged to investigate which events and activities the museum could accommodate. The exercise brought attention to the way people move through spaces and to the sensory perceptions that the building may generate.

In this exercise, the focus was thus on the routing in (and around) the building, and on the sequences of spaces that define such an "experiential route". To investigate the perception of spaces in time and through movement, the students were requested to further develop their plans and sections, and particularly, to develop a storyboard with a series of perspectives showing the different spatial experiences that the building would afford.

Figure 5: "Spatial Stories" exercise. Fragments of experiential sequence by Diana Rimniceanu
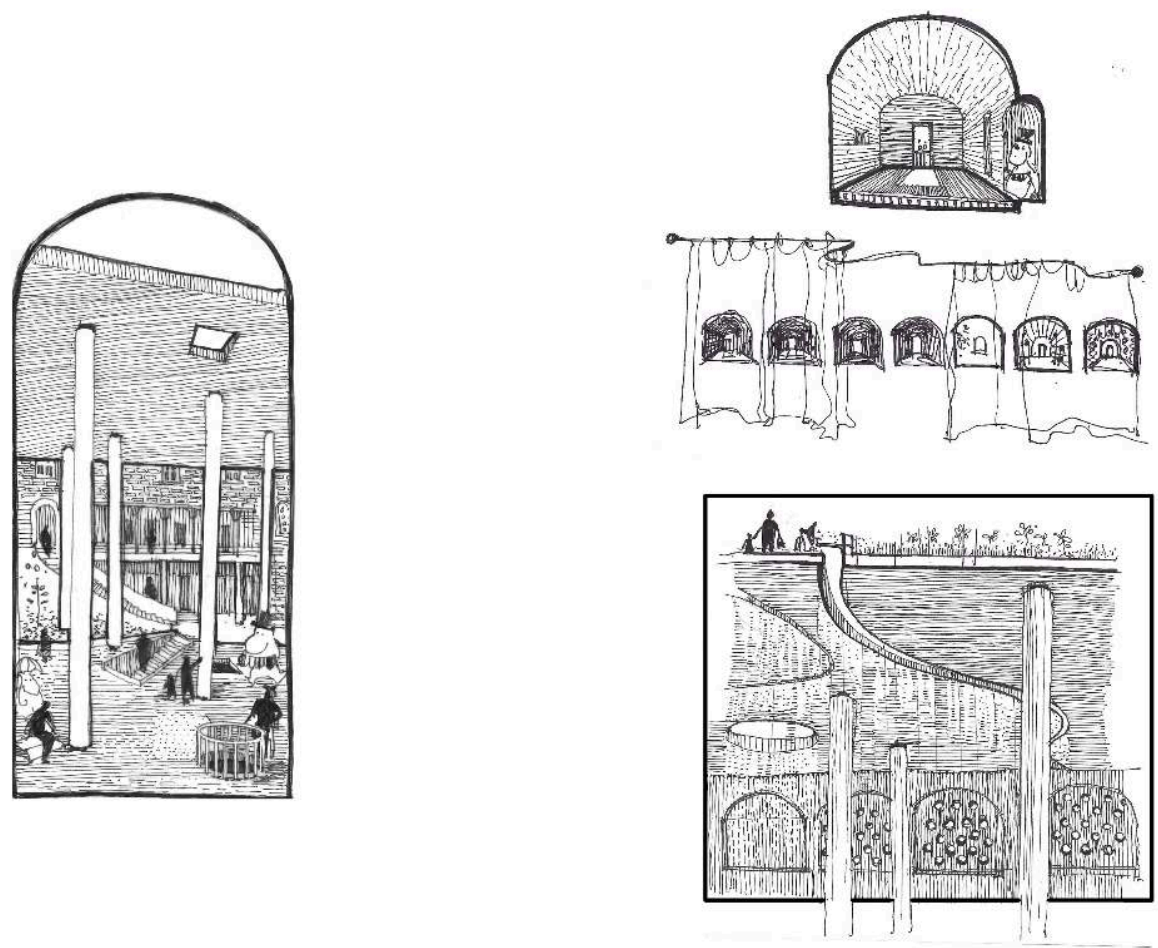

(C): Diana Rimniceanu

\section{Evoking Atmosphere}

The final task focused on the relationship between the physical materiality of the building and the more ephemeral aspects of atmosphere such as light and shadow or change of color. In this subtask, the detailed elaboration of (a part of) the building was at stake, taking into account both material and immaterial aspects, and thinking about the way the more immaterial, ephemeral aspects could be designed too. Which 
materials does the structure and shape of the building require? How do they affect the atmosphere? How do you design the interior spaces? Is there a difference between the more public spaces in the building and more utilitarian ones? Which colours are to be used? How does the light come in?

In order to address these themes, poetic description and depiction of details were used as tools for design. Short texts and sketches were meant to evoke the atmospheric qualities of the designed spaces, expressing how materials meet, how color, light and shadow would work together. In detailed models and drawings, these insights were then further elaborated.

Figure 6: “Evoking Atmosphere" exercise by Anna Luotolampi

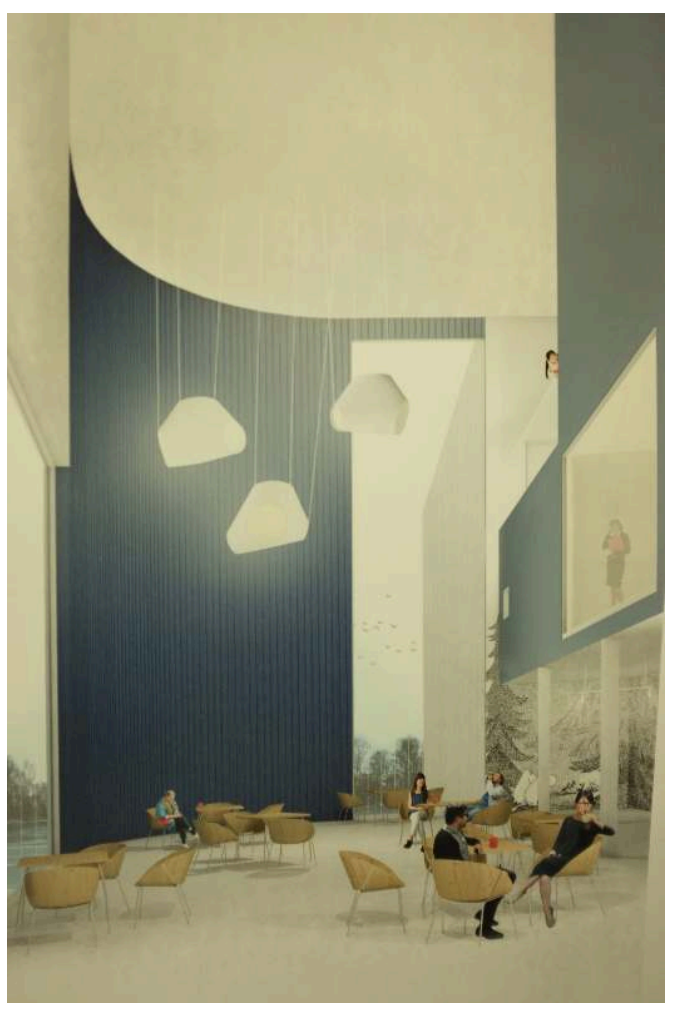

(c): Anna Luotolampi 
Figure 7: "Evoking Atmosphere" exercise by Lotta Aulamo

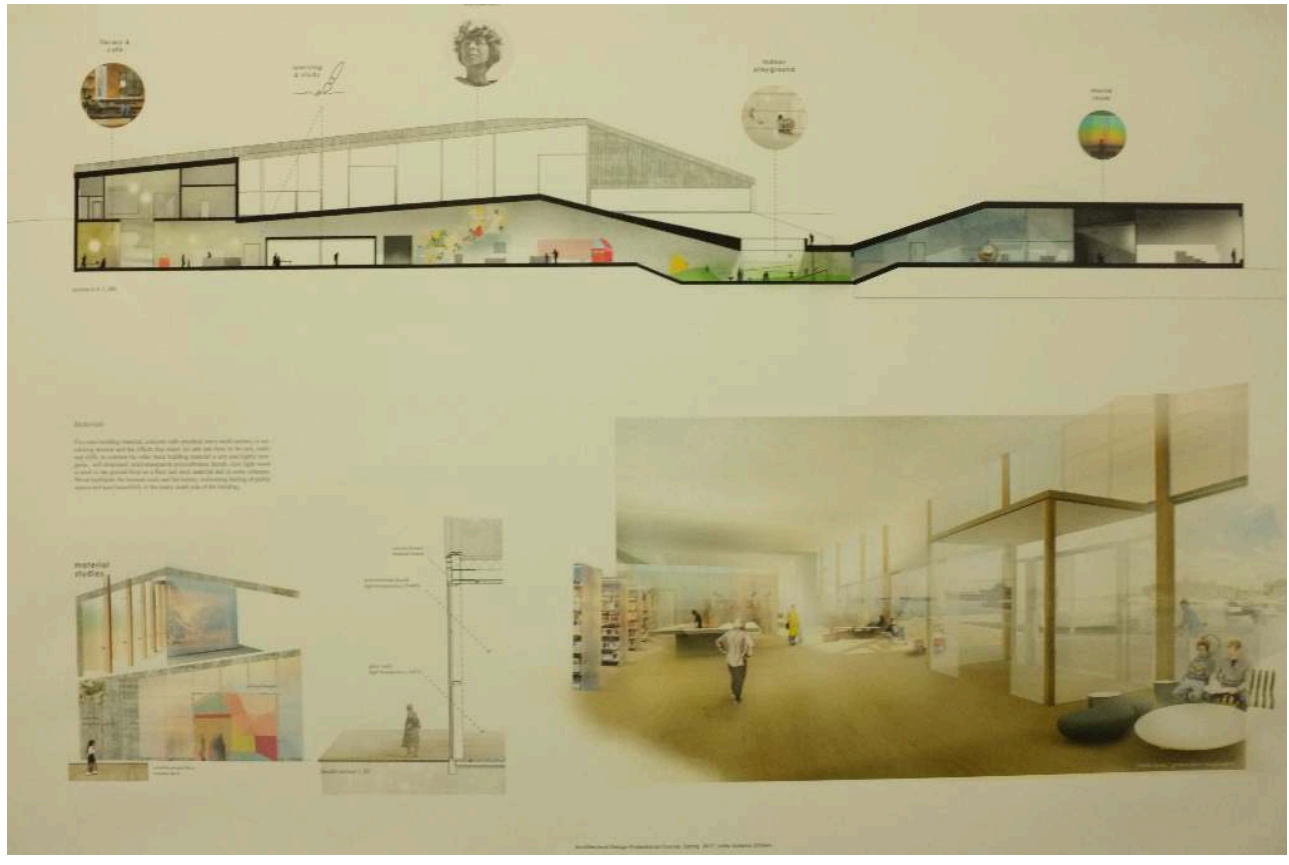

(c): Lotta Aulamo

Figure $8 \mathrm{a}, 8 \mathrm{~b}$ : Final project by Diana Rimniceanu
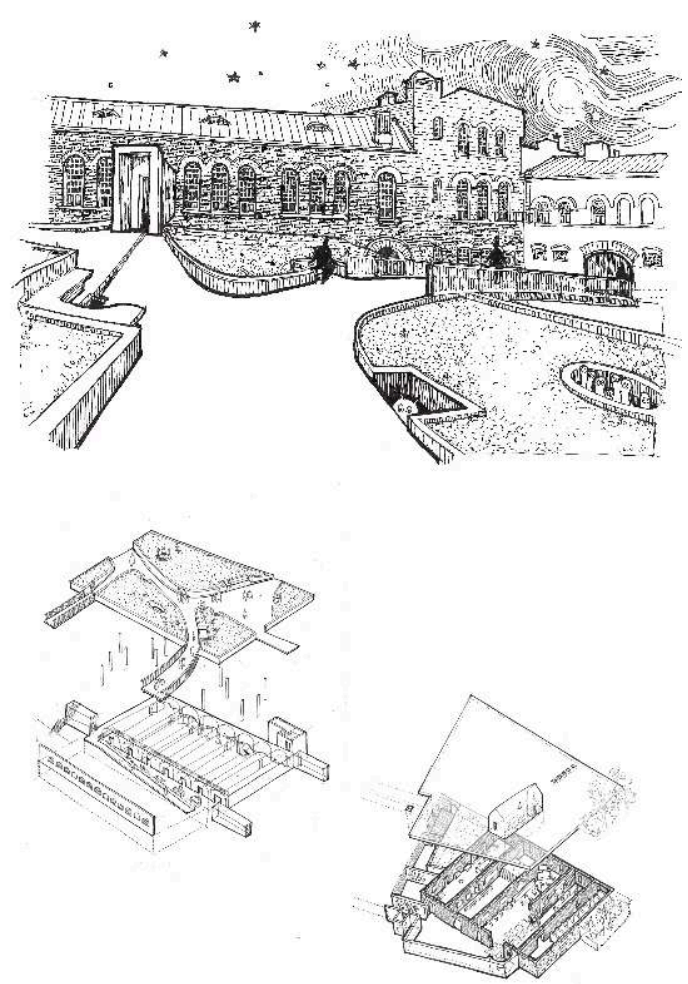

(C): Diana Rimniceanu 


\section{The Literary and the Built}

taught the students new ways to design, and to do so by combining an attentiveness to site-specific atmospheres with the power of literary imagination. Rather than the conventional site analysis, in which students study maps rather than relying on their own embodied and emotional responses to sites, the use of literary stories as a starting point for the explorations of the sites allowed the students to approach the sites more empathic and open to experience. This starting point created a mind-set for the entire course: the experiential aspects of design were foregrounded throughout the semester. In the second phase, that of "placing characters" the position of empathy was taken further, from the characters of the fictional text to the future users of the museum, taking into account spatial practices of different types of users, and investigating the spatial requirements for these practices beyond mere square meters surface: rather, thinking of the dimensions, viewing axes, color palettes and characters of the spaces as being for instance cold or warm, open or closed, dark or light, welcoming or distant. From the attentiveness to atmospheric qualities of the site towards the way atmospheres could be evokes by the building, the last two phases of the project used methods of narration and of poetic description.

21

In this particular case, the literary reference of the Moomin stories, as both a source of inspiration and an essential part of the brief, made the entry into literary modes of thinking happen in a natural way. of course, it is only seldom that an architectural project would be based on a literary source - even if there are some inspiring examples, such as the Knut Hamsun museum in Norway, a literary museum designed by Steven Holl, dedicated to the work of Norwegian writer Knut Hamsun, or the "Museum of Innocence" in Istanbul, based on Orhan Pamuk's novel of the same title. In the case of the Moomin museum course, most probably, if the Moomin characters were not so prominently part of the student's investigations, the results would have been different, most likely less playful and imaginative. However, the literary methods used in the four phases of the course could as well be used in other design studios. Especially for the first phase of the project, the site-specific explorations ("finding place"), fictional characters could be used to help students look with a different gaze.

All together, the course provided a series of literary tools that helped students to develop an awareness for the role of atmosphere in architectural design on different levels: in relation to site-specificity, in relation to the experience of future users, and in relation to material and detail. The Terristories thus connected the real and imagined territory of Finland - the real sites and the evocations of the Finnish landscape in the Moomin novels - to the imaginative power of storytelling. By seeing the design evolve through the eyes of different characters, and by imagining time and time again how spaces could be used and experienced, and how they can accommodate different moods and events, the students moved beyond the conventional "problem-solving" approach, towards more engaged, empathic and attentive ways of designing. 


\section{BIBLIOGRAPHY}

Albertsen, Niels. 2012. Gesturing atmospheres. In: Thibaud, Jean-Paul and Siret, Daniel (eds). 2012. Ambiances in Action 2nd International Congress on Ambiances (Montréal: International Ambiances Network, 2012). p. 69-74

Bachelard, Gaston. 1994 (1957). The Poetics of Space. The Classic Look at how we Experience Intimate Places. Boston, MA: Beacon Press

Böhme, Gernot. 2006. Architektur und Atmosphäre. München: Wilhelm Fink Verlag

Böhme, Gernot; Griffero, Tonino; Thibaud, Jean-Paul. 2014. Architecture and Atmosphere. Helsinki: Tapio Wirkkala-Rut Bryk Foundation

Borges, Jorge Luis. 2000. The Charles Eliot Norton Lectures 1967-68, in: This Craft of Verse. Cambridge, MA: Harvard University Press

Charley, Jonathan (ed.). 2018. Research Companion to Architecture, Literature and the City. London: Routledge

De Certeau, Michel. 1984. The Practice of Everyday Life. Berkeley: Univ. of California Press

Eco, Umberto. 1983. The Name of the Rose. New York: Helen and Kurt Wolff/ Harcourt

Edwards, Sarah; Jonathan Charley. 2012. Writing the Modern City. Literature, architecture, modernity. London: Routledge

Gadanho, Pedro; Susana Oliveira (eds). 2013. Once Upon a Place. Architecture and Fiction. Lisbon: Caleidoscopio

Grafe, Christoph; Havik, Klaske; Maaskant, Madeleine (eds.). 2006. OASE 70, Architecture\&Literature Reflections / Imaginations. Rotterdam: nai010 publishers

Gibson, James J. 1979. The Ecological Approach to Visual Perception. Boston, MA: Houghton Lifflin

Griffero, Tonino. 2014. Atmospheres: Aesthetics of Emotional Spaces. London: Ashgate

Grillner, Katja. 2005. Writing Architecture. 01.AKAD Beginnings- Experimental Research in Architecture and Design. Stockholm: AKAD

Hall, Edward T. 1990 (1966). The Hidden Dimension. New York: Anchor Book Editions

Havik, Klaske; Tielens, Gus; Teerds, Hans (eds.). 2013. OASE 91, Building Atmosphere. With Juhani Pallasmaa and Peter Zumthor. Rotterdam: nai010 publishers

Havik, Klaske. 2014. Urban Literacy. Reading and Writing Architecture. Rotterdam: nai010 publishers Havik, Klaske; Oliveira, Susana et al. (eds.) 2016. Writingplace: Investigations in Architecture and Literature. Rotterdam: nai010 publishers

Havik, Klaske; Veldhuisen, Sebas. 2011. Terristories - an Educational Method for Sustainable, Site-specific Research and Design. In Voyatzaki, Maria (ed.) Teaching a New Environmental Culture. The Environment as a Question of Architectural Education. Brussels: EAAE European Association for Architectural Education

Mallgrave, Harry Francis. 2018. From Object to Experience. The New Culture of Architectural Design. London: Bloomsbury 
Nerdinger, Winfried (ed.). 2007. Architektur wie sie im Buche steht, Fiktive Bauten und Städte in der Literatur. München: Architekturmuseum der Technische Universität München, Verlag Anton Pustet

Pérez-Gómez, Alberto. 2016. Attunement. Architectural Meaning after the Crisis of Modern Science. Cambridge MA: The MIT Press

Proust, Marcel. 2006 (1919). Remembrance of Things Past. New York: Wordsworth Editions

Semper, Gottfried. 1989 (1851). The Four Elements of Architecture and Other Writings. Trans. Harry

F. Mallgrave and Wolfgang Herrmann. Cambridge: Cambridge University Press

Sioli, Angeliki; Jung, Yoonchun. 2018. Reading Architecture: Literary Imagination and Architectural Experience. London: Routledge

Thibaud, Jean-Paul; Siret, Daniel. 2012. Ambiances in Action $2^{\text {nd }}$ International Congress on Ambiances. Montréal: International Ambiances Network

Tuan, Yi-Fu. 1974. Topophilia. A Study of Environmental Perception, Attitudes and Values. Minneapolis: University of Minnesota Press

\section{ABSTRACTS}

By recognizing the potential of literary language in the description of architectural atmospheres, this contribution aims to confront the shortcomings of conventional pedagogical approaches in architecture that often fail to provide an in-depth understanding of the experiential aspects of place. To contribute to the development of appropriate instruments of analysis and design to read and describe urban atmosphere, this article combines two main insights: first, that it is of crucial importance to investigate site-specific atmospheres to understand how people experience the urban territories they use or inhabit; and second, that it is through literary devices that atmospheres can be read and described. By bringing together these insights, this article aims to propose pedagogical exercises that help students of architecture to develop a better understanding of the experiential aspects of site-specificity. By adding to the conventional tools of architect and planners a set of tools inspired by literature, it hopes to offer students in architecture more appropriate tools to describe, respond to, and produce site-specific atmospheres. It will illustrate the potential of this approach by presenting an example of the use of literary methods in architectural education, in Tampere, Finland.

En redonnant crédit au langage littéraire comme outil pour décrire les ambiances architecturales, cette contribution propose de dépasser les approches pédagogiques conventionnelles en architecture qui, souvent, ne nous permettent pas de saisir l'expérience sensible des lieux. Avec l'objectif de contribuer au développement d'outils d'analyse et de conception pour lire et décrire les atmosphères urbaines, cet article associe deux idées principales : la première qu'il est de prime importance d'étudier les ambiances d'un lieu pour comprendre la manière dont les habitants en font l'expérience; la deuxième que les outils littéraires nous permettent de lire et décrire ces ambiances. En rassemblant ces deux idées, notre contribution met en discussion des exercices pédagogiques dont la vocation est d'amener les étudiants en architecture à mieux comprendre les qualités d'un lieu à travers les manières dont on en fait l'expérience. En adjoignant aux outils conventionnels des architectes et des urbanistes, un ensemble d'outils inspirés par la littérature, nous espérons offrir aux étudiants des outils plus appropriés pour décrire, répondre à et concevoir les ambiances particulières d'un lieu donné. Cet 
article illustre le potentiel de cette approche à travers l'exposé d'un retour d'expérience pédagogique en architecture mettant en jeu ces méthodes littéraires à Tampere en Finlande.

\section{INDEX}

Keywords: atmosphere, site-specificity, narrative, architecture, architectural education Mots-clés: ambiance, qualités d'un lieu, narration, architecture, pédagogie en architecture

\section{AUTHOR}

\section{KLASKE HAVIK}

Klaske Havik, Chair of Methods \& Analysis at the Department of Architecture at TU Delft, the Netherlands. Havik was visiting professor of Architectural Design at Tampere University of Technology from 2015-2017.Her books Urban Literacy. Reading and Writing Architecture (2014) and Writingplace (edited volume, 2016) relate questions of architectural experience to literary language. Havik initiated seminars, courses and debates on architectural atmospheres in the Netherlands and Finland, and edited (among many other issues) the OASE journal issue Building Atmosphere with Juhani Pallasmaa and Peter Zumthor (Nai010, 2013). She initiated the Writingplace Laboratory for architecture and literature and the Writingplace journal for architecture and literature. Havik is leading the EU Cost network Writing Urban Places. k.m.havik@tudelft.nl 